This is an electronic reprint of the original article. This reprint may differ from the original in pagination and typographic detail.

Author(s): Saloviita, Timo; Schaffus, Tina

Title: $\quad$ Teacher attitudes towards inclusive education in Finland and Brandenburg, Germany and the issue of extra work

Year: $\quad 2016$

Version:

Please cite the original version:

Saloviita, T., \& Schaffus, T. (2016). Teacher attitudes towards inclusive education in Finland and Brandenburg, Germany and the issue of extra work. European Journal of Special Needs Education, 31(4), 458-471.

https://doi.org/10.1080/08856257.2016.1194569

All material supplied via JYX is protected by copyright and other intellectual property rights, and duplication or sale of all or part of any of the repository collections is not permitted, except that material may be duplicated by you for your research use or educational purposes in electronic or print form. You must obtain permission for any other use. Electronic or print copies may not be offered, whether for sale or otherwise to anyone who is not an authorised user. 
Teacher attitudes towards inclusive education in Finland and Brandenburg, Germany and the issue of extra work

\author{
Timo Saloviita \\ University of Jyvaskyla \\ Tina Schaffus \\ University of Potsdam
}

Timo Saloviita, Department of Teacher Education, University of Jyvaskyla, PO Box 35, 40014 Jyvaskylan yliopisto, Finland. Phone: +358 408053373, E-mail:

timo.saloviita@jyu.fi

Tina Schaffus, Potsdamer Zentrum für empirische Inklusionsforschung, Universität Potsdam, Karl-Liebknecht-Str. 24-25, 14476 Potsdam, Germany. Phone +01725276772, E-mail: schaffus@uni-potsdam.de 


\begin{abstract}
Positive teacher attitudes are considered an important prerequisite for the successful inclusion of students with special educational needs in the mainstream classrooms. This study surveyed teacher opinions about inclusion in Finland $(\mathrm{N}=298)$ and Brandenburg, Germany $(\mathrm{N}=163)$, two educational systems in which the number of students transferred to segregated special education is exceptionally high in international comparison. For the measurement of attitudes a ten-item scale, Teachers' Attitudes towards Inclusive Education (TAIS) was used. The results showed that Finnish teachers were more positive towards inclusion than Brandenburg teachers $(d=0.46)$. The Brandenburg teachers were especially worried about the extra work caused by inclusion. This concern was possibly related to the different structures of educational organisation. Additional support services were more easily available for the Finnish teachers than for their Brandenburg colleagues. It is argued that teachers' concerns should be addressed to promote inclusion in schools.

Keywords: teacher attitudes, inclusive education, Finland, Brandenburg, disabilities, special education
\end{abstract}




\section{Teacher attitudes towards inclusive education in Finland and Brandenburg, Germany and the issue of extra work}

\section{Introduction}

Teacher attitudes towards inclusive education have been an amply researched topic for decades (Scruggs and Mastropieri 1996). As initially defined in the Salamanca Statement, inclusive education refers to a form of schooling in which the supports required by a child with special educational needs is brought into the mainstream classroom in order to ensure effective education (UNESCO 1994). By bringing the needed help into a normal environment it was considered possible to integrate almost all students with disabilities into mainstream education so that special schools or special classes should remain only an infrequent exception. This idea was highlighted in the Salamanca Statement by launching a brand new concept of 'inclusive education' to denote a paradigmatic shift in thought. Previously, it was generally maintained that the 'integration' of a child was possible if he or she first was able to achieve the skills needed by the school through rehabilitation. Now, along with the new way of thought, the responsibility for change was put to the school organization itself. Even if the concepts of integration and inclusion originally conveyed this paradigmatic contrast, in everyday language they are mostly used interchangeably nowadays. No distinction between them is made in the remainder of this study.

When considering the prerequisites for the inclusion of children with special educational needs (SEN) in mainstream classrooms, it seems obvious that an essential requirement for success is the teachers' accepting attitude towards these children. This was also verified in a study on 8,200 Dutch children with SEN, in which teachers with more positive attitudes attained better learning results than non-accepting teachers (van der Veen, Smeets, and Derriks 2010). In promoting inclusive education, it is therefore vital to support and enhance the teachers' welcoming attitude towards children with disabilities. 
The importance of developing traditional school systems to be more inclusive has become even more pronounced after the principle of inclusive education became part of international law through the adoption of the Convention on the Rights of Persons with Disabilities (United Nations 2006). Article 24 of the convention confirms the rights of persons with disabilities not only to education but also to 'an inclusive education system at all levels'. By the end of 2015, the convention has been ratified by most countries worldwide (United Nations 2015). Despite these developments in legislation, national policies on special education have remained more conservative, and traditional segregated models of special education have survived. The exception is Italy, where almost all special education schools and classrooms were already closed in the seventies (Canevaro 2007).

An important obstacle in the development of positive attitudes among teachers toward inclusion may be their fear of extra work caused by a child with special educational needs. According to Etzioni (1964), it is a universal tendency of social organizations to select their members in order to save costs caused by control and socialization. The pressure for selection seems obvious when considering that approximately $5 \%$ of members of any organization are usually responsible for 95\% of all disturbances (Etzioni 1964; Horner, Sugai, Todd and Lewis-Palmer 2005, 362). Some authors have seen schools' placement policies in special education as expressing this tendency of organizational selection (Kivinen and Kivirauma 1988; Skrtic 1991). Indeed, empirical data have shown that teachers' selection tendencies can be strong in the context of both general and special education. A representative Finnish study found that mainstream or special education teachers only considered $47 \%$ of their students with SEN to be in the right place in their classrooms. These teachers recommended a more restrictive placement for $33 \%$ of their students with SEN and less restrictive placement for $20 \%$ of their students with SEN (Saloviita and Leskinen 2016).

\section{A Study of Teacher Attitudes}


Comparative research on teacher attitudes towards inclusive education in different countries may have the advantage of revealing the teacher attitudes' connections to some larger societal variables and thus help us to understand the prerequisites for attitude change. A review of 29 studies published between 1958 and 1995 found no differences between the attitudes of the teachers from USA, Australia and Canada (Scruggs and Mastropieri 1996). However, differences emerged from a large UNESCO study involving 14 countries Australia, Botswana, Colombia, Czechoslovakia, Egypt, Jordan, Italy, Mexico, Norway, Portugal, Senegal, Thailand, Venezuela and Zambia (Bowman 1986). It was observed that teachers were more positively disposed towards integration if the national legislation favoured it, but they were more negatively inclined if there was a large, segregated special education sector in the country (Bowman 1986).

Leyser, Kapperman, and Keller (1994) compared teacher attitudes towards mainstreaming in six nations - the USA, Germany, Israel, Ghana, Taiwan and the Philippines. The most supportive views were expressed by teachers in the USA, followed by Germany. The teachers in the other countries mainly showed a neutral disposition. The effect size $(d=$ 1.65) between the highest (the USA) and the lowest scores (Israel's non-kibbutz teachers) indicated a large discrepancy. In interpreting their findings, the authors referred to the cultural, ethnic and religious differences among the teachers in the six countries. The positive attitudes of the US teachers were explained by the progressive school legislation on the integration of students with disabilities in the least restrictive environments since the 1970s. For regular classroom teachers, instructional materials, consultations, team teaching, assistants, in-service training and other types of support were available, which possibly led to the increased integration of students with disabilities and to the more positive teacher attitudes towards mainstreaming (Leyser, Kapperman, and Keller 1994). The positive attitudes of German (Bavarian) teachers were considered a surprise because no similar 
support or legislation was available in their country. In the other comparison countries, the more negative attitudes were explained by the deficiencies in teacher training, the small percentage of integrated students or the absence of educational opportunities for children with disabilities (Leyser, Kapperman, and Keller 1994).

A few studies have compared Finnish teachers with their counterparts from other countries. Only the comparisons with national sample sizes exceeding 100 are reviewed in this paper. When the Finnish regular education teachers were compared with their Zambian peers, it was observed that the latter preferred more segregated environments for almost all the disability groups mentioned (Moberg 2003). It was hypothesised that the more negative attitudes of the Zambian teachers might have reflected the lack of necessary support services.

The Finnish teachers' attitudes were also found to be more positive than those of their South African colleagues (Engelbrecht et al. 2013; Savolainen et al. 2012). Moreover, the Finnish teachers expressed lower levels of concerns associated with inclusion and more positive general sentiments towards disabilities. The authors explained these differences on the basis of the cultural-historical differences between the two countries (Engelbrecht et al. 2013). According to them, although the Finnish basic education was strongly based on separate programmes, there had been a recent systematic reform in favour of a more inclusive direction. In South Africa, the constitution strongly emphasised human rights, and the government defined inclusive education as an academic goal (Engelbrecht et al. 2013). However, the development of inclusive education suffered from the lack of concrete strategies and resources in the country. Consequently, increased tensions developed between the national agenda and contextual realities (Engelbrecht et al. 2013).

The present study aims to compare teacher attitudes towards inclusion in Finland and Germany. Both countries are highly developed European welfare states, each with an advanced educational system that includes an exceptionally segregated special education 
sector. Historically, Germany has been a model for the development of Finnish society in many aspects, either directly or via Sweden. The following sections provide more detailed descriptions of the structures of basic education and special education, teacher training and the development of the educational policy on special education in Finland and the federal state of Brandenburg, which was chosen as a comparison state among the sixteen federal states of Germany.

\section{Premises for inclusive Education in Finland}

Finland has about 5.5 million inhabitants in 2015. The Finnish compulsory basic education encompasses nine years and is for children between 7 and 16 years old. Since 1997, it has provided schooling for all children, including those with the most severe disabilities. Students usually attend the school that is nearest their residence. The schools follow a national core curriculum, with local adjustments. The education in grades $1-6$ is mainly provided by classroom teachers who have a five-year master's degree in education. The students in grades 7-9 are instructed by subject teachers, who also have a five-year master's degree in education, including one year of pedagogical studies which equals 60 credits as defined in the European Credit Transfer System (ECTS). The special education teachers have completed a five-year special education teacher training in the university or about a year's training (60 ECTS) in special education as part of or in addition to their teacher studies. Teachers of students with severe disabilities have somewhat lower competency requirements than other special education teachers (Finnish National Board of Education 2015).

The students with SEN are usually taught in special education classrooms, which are situated in the mainstream basic schools. During the 2012-2013 school year, 539,545 students were enrolled in basic education (Statistics Finland 2015a). Of these students, 7.6\% were diagnosed with SEN (Statistics Finland 2015b). The percentage of students in segregated special education was $4.7 \%$ when segregation was defined as either attendance in 
a special school $(1.0 \%)$ or special education classroom in the mainstream school at least $51 \%$ of the instruction time (3.7\%). The remaining $2.9 \%$ of students with SEN attended a special education classroom less than half of the time — or, in some cases, were fully integrated into mainstream education (Statistics Finland 2015b). Additionally, 22.3\% of the students, mostly without a SEN diagnosis, participated in part-time special education outside their regular classrooms (Statistics Finland 2015c). Typically, this part-time special education comprised only one or two hours a week per student.

As of 2016, Finland has not yet ratified the Convention on the Rights of Persons with Disabilities (United Nations 2006); neither does the Finnish basic school legislation include any principle of integration. Instead, it stipulates that the special educational placement must be determined on the basis of the children's best interests and on the available resources (Act on Basic Education 1998). By law, teachers make the final decision concerning the children's educational placement.

In 2010, the state subsidy was revised, which instantly affected the number of students transferred into special education. By law, the costs of special education were transferred from the state to the local municipalities responsible for basic education (Act on the Funding of Education and Culture 2009). This put an end to the long-lasting increase in the number of students transferred to special education classrooms (Statistics Finland 2015c). The reform did not actually indicate an interest towards inclusive education but was mainly motivated by monetary reasons. The change in the Act on Basic Education in 2010 imposed some novel requirements before students could be transferred to special education. Some authors have interpreted these restrictions as an indication of the political will to promote inclusive education (Engelbrecht et al. 2013). This might be a too bold interpretation, because the new requirements could also be easily circumvented if desired. Additionally, in the Amendment 24.6.2010/642 any references to the primacy of mainstream placement over segregated 
placement were at the same time removed from the Act (Act on Basic Education 1998). An overall effect of the new amendments was the decrease in the percentage of fully segregated students from 3.9\% to 2.9\% between 2010 and 2014 (Statistics Finland 2015a, 2015b). This was probably due to the local communities' unwillingness to start paying the extra costs of segregated special education. The strong influence of economic considerations on the rate of the transfers to special education has been previously confirmed by international comparisons (European Agency for Development in Special Needs Education 1999).

\section{Premises for inclusive Education in Brandenburg}

Germany comprises 16 federal states (Bundesland); each has its own system of organising public education within the common premises of the German constitution. One of the federal states, Brandenburg surrounds the city of Berlin and has about 2.5 million inhabitants. As a rule, compulsory education in Brandenburg includes children belonging to the 6-16 age group. All children should complete six grades of basic school (Grundschule). Next, they can attend high school (Gymnasium) for six years (grades 7-12). An alternative is the more practically oriented main school (Hauptschule), with the following three forms: Realschule (grades 7-10), Gesamtschule (grades 7-10 or 7-13) and Oberschule (grades 1113). Compulsory education is finished after 10 years of studies, which can be completed in either the Realschule or the Gesamtschule. Students can then continue their education in either the Gesamtschule or the Gymnasium. In both schools, the students can earn a high school diploma. The students from the Realschule typically continue in the Oberschule, with a more practical orientation leading to vocational schools (Bildungskomission der Länder Berlin und Brandenburg 2003).

After earning a five-year master's degree in education, teachers are required to finish an 18-month 'Vorbereitungsdienst' to obtain full teacher competence (Ministerium für Bildung, Jugend und Sport 2016). It contains both teaching practice and participation in study seminars 
and concludes with a final examination. Every primary-level teacher (Grundschule) should study three subjects, two of them being the main subjects. The secondary-level teachers study two subjects. Universities may emphasise different areas of specialisation. For example, in the University of Potsdam, students taking up primary teacher education have the possibility to specialise in inclusive education.

In Brandenburg, about 223,000 children were enrolled in basic education in the 20122013 school year. Of this total population, 16,195 or $7.2 \%$ were diagnosed as SEN students. Of them 9,387 or $4.2 \%$ entered special education schools (Förderschule), and 3.0\% were integrated into the mainstream classrooms (Amt für Statistik Berlin-Brandenburg 2013, p. 28). In 2015, a total of 82 special schools were in operation (Ministerium für Bildung, Jugend und Sport 2015).

In 2009, Germany ratified the Convention on the Rights of Persons with Disabilities. The Brandenburg law on basic education also includes the principle of integration. According to the law, children with and without SEN should be educated together. However, two conditions must be first fulfilled. The necessary resources for integrated education must be available, and a child's parents must accept the regular school placement (Landesregierung Brandenburg 2002). No more than four students with SEN are allowed to be assigned to the same regular classroom, and the class size is limited to a maximum of 23 students if a student with SEN is placed in the classroom (SopV 2007).

The teacher attitudes towards inclusive education in Finland and Germany were compared through teacher surveys. Because the school system in Germany differs from state to state, only one federal state - Brandenburg - was chosen for comparison. This study aimed to relate the observed attitudes to some teacher variables and to discuss whether the national differences in the educational legislation and structure could explain the variations in teacher attitudes (Bowman 1986). 


\section{Methods}

\section{Data Collection}

The Finnish data were collected by four groups of student volunteers who attended the scientific methodology course in their preservice teacher education. Each group of students had been given a sample of Finnish municipalities, altogether consisting of 45 out of the total of 317. The municipalities were randomly selected in alphabetical order from the list of Finnish municipalities, excluding the Swedish-speaking communities. The teachers who were recruited for the survey taught grades 1-9 in the Finnish compulsory schools. The student volunteers collected the teachers' e-mail addresses from the schools' websites. If the teachers' e-mail addresses were unavailable, their school was excluded from the sample. The teachers with e-mail addresses were then sent messages that contained the hyperlink to the survey, which was prepared with the SPSS mrInterview software. The cover letter stressed that the survey was anonymous, and no participant could be identified. One reminder was sent to all the recipients.

The data from Brandenburg were collected by the second author, who obtained the teachers' e-mail addresses from the schools' websites. All the schools providing education in grades 1-13 in Brandenburg were included in the sample, except those schools whose websites did not show the teachers' e-mail addresses. No reminder was sent. The processing and storage of the data followed the ethical standards set by the National Advisory Board on Research Ethics in Finland (2009).

\section{Participants}

A total of 427 Finnish teachers (24\%) responded to the survey. Only the responses of the classroom teachers $(n=188)$ and the subject teachers $(n=110)$ were selected for further analysis. These respondents comprised $81 \%$ women and $19 \%$ men. Their mean age was 46 , and they had been teaching for 17 years on average. 
In Brandenburg, the survey respondents totalled 169 teachers (19\%). The special education teachers $(n=6)$ were excluded from further analyses; they had a small number in the sample because their e-mail addresses were seldom published in the special schools' websites. The remaining participants consisted of $78 \%$ women and $22 \%$ men. Their mean age was 46, and their length of teaching averaged 19 years. All the respondents possessed some teacher qualifications, mostly for secondary education $(n=133)$ or basic education $(n=34)$.

[Table 1 near here]

\section{Measurement of attitudes}

The Teachers' Attitudes towards Inclusive Education Scale (TAIS) was used in this study (Saloviita 2015). The scale was intended to measure the teacher attitudes in terms of how the concept was defined in the Salamanca Statement of (UNESCO 1994). The ten items in the questionnaire were measured by a 5-point Likert scale, ranging from 'strongly disagree' to 'strongly agree', with a neutral mid-point. The scoring of six items was reversed for the calculation of the sum total (see Table 1). The scale's reliability has varied between $\alpha=0.81$ and 0.90 in the five samples comprising preservice or in-service teachers (Saloviita 2015). It had been shown as one-dimensional when the in-service teacher population was measured (Saloviita 2015). The content validity of the scale is enhanced by the versatile contents it embraces. As presented in Table 1, the items contain fields of expected outcomes, rights of the child, workload of the teacher and inclusion as a value. The TAIS scale indicated good divergent validity when compared with the construct of self-efficacy towards inclusion (Saloviita 2015). The convergent and divergent validity of the scale was also shown (Saloviita 2015) by correlating the TAIS scores with the subscales of the SACIE-R scale by Forlin, Earle, Loreman, and Sharma (2011). The TAIS scale was originally developed through psychometric analysis in which the number of included items was stepwise reduced, 
as described by Saloviita (2015). The scale was translated from Finnish into English and proofread by a native English speaker. The English version was translated into German by a native German speaker. In order to detect any inconsistencies between the original and the translated texts, the German translation was compared with the original Finnish text by two persons who were fluent in both languages and were professionals in the field of special education. They confirmed that the diagnostic terms used in the test items had the same meaning in both countries and that the administrative concepts of special education, special education needs and special education teacher had comparable contents. The term special education classroom was in some cases translated in the German version as 'special school', because in Brandenburg no special education classrooms were situated in the mainstream schools, as was the case in Finland. Data were analysed with SPSS version 22, using principal-axis factor analysis, Cronbach's alpha, descriptive statistics, correlations, simple statistical tests and Cohen's $d$ as a measure of effect size.

\section{Results}

\section{Properties of the TAIS}

The reliability values of the TAIS were $\alpha=0.83$ in the German sample and $\alpha=0.89$ in the Finnish sample, as measured by Cronbach's alpha. The principal-axis factor analyses were performed separately for the Finnish and the Brandenburg data, using varimax rotation. In the German data, a three-factor solution appeared with a strong first factor, which explained $37 \%$ of the total variance and was named 'inclusion as a value'. The second factor explained $7 \%$ of the total variance and was called 'outcomes of inclusion'. The third factor explained $6 \%$ of the variance and was labelled 'workload concerns'.

In the Finnish sample, a two-factor solution appeared with a strong first factor, which explained $46 \%$ of the total variance and was named 'inclusion as a value'. The second factor explained $5 \%$ of the total variance and was called 'outcomes of inclusion'. Because of the 
different factor structure and the strong first factor, the data analysis was continued on the basis of the sum total scores of the scale.

[Table 2 near here]

\section{Sum Score Results}

The Finnish sample had two teacher categories - classroom teachers (grades 1-6) and subject teachers (grades 7-9). The Brandenburg sample comprised three categories Grundschule (grades 1-6), Hauptschule (grades 7-13) and Gymnasium (grades 7-13) teachers. No statistically significant differences existed between the national teacher categories in the attitudes towards inclusion (Table 2). However, in the Brandenburg sample, the Hauptschule teachers had somewhat higher scores than those of the other two categories, even if the value of $F$ was not statistically significant. Because of the similarity of the group means, all the teacher categories were combined by state in our further analyses.

The TAIS sum scores showed the Finnish teachers' more positive attitudes towards inclusion compared to the Brandenburg teachers (Table 2). As measured by Cohen's $d$, there was a medium-level difference $(d=0.46)$. In both states, the mean remained somewhat under the mid-point of the scale.

In the Finnish sample, female teachers $(\mathrm{M}=27.8)$ were more positively inclined towards inclusion than men $(M=25.4)$, with $t(296)=2.12, p=0.035$. In Brandenburg, the difference between women $(M=24.4)$ and men $(M=23.2)$ was not statistically significant $t(161)=1.05, p=0.294$.

In the Finnish sample, the teacher's age did not correlate with the TAIS sum score $(r=$ 0.02), while the Brandenburg sample showed a low negative correlation $(\mathrm{r}=-0.22)$. When three age groups $(26-35,36-50$ and 51-65) were compared in the German sample, using the $F$-test and post hoc test (Bonferroni), it was found that the oldest age group $(\mathrm{M}=22.6)$ differed significantly from the youngest age group $(\mathrm{M}=26.0)$. Cohen's $d=0.62$ indicated a 
medium-level difference in the group means.

\section{Item-specific Results}

Table 1 shows the item-specific results of the comparison between Finland and Brandenburg. The percentages indicated the proportion of the participants who agreed or strongly agreed with each item. Statistical tests were performed for the means of the two groups, and Cohen's $d$ was calculated to show the effect size. The scale items in Table 1were ordered on the basis of the content analysis of the scale, with four content areas - expected outcomes, the child's rights, the teacher's workload and inclusion as a value (Saloviita 2015).

The difference between the item scores from the two states was statistically significant in every item. In all the three items of the content area of expected outcomes, the Brandenburg teachers valued special classrooms higher than the Finnish teachers did. Only one fourth of the German teachers expected that the education of children with SEN could be effectively supported in the mainstream classrooms, in contrast to 54\% among the Finnish teachers. Similarly, more often than their Finnish colleagues, the German teachers deemed it the right of children with SEN to be taught in the special education classrooms.

The largest difference between the states was observed in the two items evaluating the teacher's workload. More often than their Finnish peers, the German teachers expected that inclusive placements produced additional work for teachers. The effect sizes were at the level of one standard deviation, indicating large differences in the item scores. Almost all the German teachers $(90 \%)$ agreed that children with SEN would create extra work for teachers if these students were placed in the mainstream classrooms.

The items measuring inclusion as a value produced somewhat contradictory results. Twice more often than their German counterparts, the Finnish teachers agreed that students with SEN should be educated in mainstream classrooms. However, the German teachers were more willing than their Finnish colleagues to accept students with attention deficit 
hyperactivity disorder (ADHD) or emotional and behavioural problems in their classrooms (Table 1).

\section{Discussion}

The present study compared teacher attitudes towards inclusive education in two states

- Finland and the federal state of Brandenburg. Both states had a high proportion of students transferred to segregated special education, rising in Brandenburg to $4.2 \%$ and in Finland to $4.7 \%$ of all the students in basic education during the 2012-2013 school year (Amt für Statistik Berlin-Brandenburg 2013; Statistics Finland 2015b). These percentages are among the highest reported in the world (Australian Bureau of Statistics 2013; European Agency for Special Needs Education 2012; National Center for Education Statistics 2016; Statistics Canada 2012).1

Despite this similarity, the comparison indicated that the Finnish teachers' attitudes towards inclusive education were more positive than those of their Brandenburg colleagues. Other differences were also observed. First, while women were generally more positively disposed towards inclusion than men, the gender difference was statistically significant only in Brandenburg. Second, there was no correlation in Finland between the teacher's age and attitudes, while in Brandenburg, younger teachers had somewhat more positive attitudes than their older colleagues.

More differences between the countries were found when the individual items of the TAIS were reviewed. Particularly, the Brandenburg teachers were much more concerned than their Finnish peers about the possible extra work caused by inclusive placements. They also

1 In the present study, segregated placement is defined as a placement in special school or special education classroom at least $51 \%$ of the time. The Finnish data published by the European Agency for Special Needs Education (2012, 21-22) report higher numbers of students in fully inclusive settings. This is because the National Board of Education from where the data come has defined full inclusion more broadly as containing all students whose instruction happens at least sometimes (at least $1 \%$ of the time) in a mainstream environment. 
assumed less often than the Finnish teachers did that inclusion could have positive effects, and they more often regarded the special classroom placement as the child's right.

The factor analysis of the TAIS showed a strong first factor (inclusion as a value) in both country samples. A second factor (outcomes of inclusion) emerged in the Finnish sample, whereas a three-factor structure (inclusion as a value, workload concerns and outcomes of inclusion) appeared in the German sample. However, these additional factors explained only a small percentage (5-7\%) of the total variance, indicating that the TAIS could be used as a unified measure. The scale had a high reliability in both samples.

The reasons for the observed differences in teacher attitudes between the countries remain uncertain in this study, but some guesses can be made. Bowman (1986) reported that a larger scope of segregated special education in a country was associated with more negative teacher attitudes towards inclusion. Between Finland and Germany, there were no large differences in the proportion of students transferred to segregated special education. However, Brandenburg's educational system was more segregating because special education was organised in separate schools. In Finland, only $1.0 \%$ of the students attended a separate special school, while four times more were educated in the special education classrooms located in the mainstream schools. This difference might partly explain the more negative attitudes of the Brandenburg teachers.

The school legislation in Finland (in contrast to Brandenburg's) does not stipulate any principle of integration. Still, this should not cause a major difference because in both countries, the final decision about the placement is left to the teachers, who are allowed to exercise their judgement on the basis of loosely defined criteria. These open criteria allow teachers considerable autonomy in decision making. In Finland, the decision criteria are the 'the child's best interests' and the 'available resources'. In Brandenburg, the decision criteria are the principle of integration and resources. Additionally, parents can refuse integrated 
placements for their child, but they have no similar right concerning segregated placements.

The example of the Italian school system shows that teachers can also support a system that is based on the full inclusion of students with disabilities. A large survey found that $74 \%$ of the mainstream teachers agreed with the statement 'I am willing to teach students with learning problems [difficoltá di apprendimento] in my class' (Cornoldi et al. 1999). The keyword may be the resources. In Italy, an inclusive placement is by law accompanied by a smaller class size and the assistance of a special education teacher (called a 'support teacher' or insegnante di sostegno) in the classroom (Associazione TreeLLe and Caritas Italiana e Fondazione Agnelli 2011; Canevaro 2007). These measures have possibly warranted the teachers' support for inclusive policy in Italian schools for over 30 years.

In Finland, similar but less compulsory practices are applied. Over the past two decades, the occupational group of classroom assistants has increased in number, now close to 10,000 , in comparison to the special education teachers (Kuntatyönantajat 2015). Thus, when a child with SEN is considered for inclusion, the teacher also has a high possibility to have extra hands in his or her classroom although it is not required by law. Unfortunately, the use of teaching assistants does not seem to guarantee quality education; a large study from Britain showed that teaching assistants actually had negative effects on children's learning (Webster et al. 2010).

In Brandenburg, the law guarantees the reduction of the class size and limits the number of children with SEN in a single mainstream classroom. These measures may be insufficient when the integration of a child with SEN is considered. It seems that extra hands are always needed. The lack of extra support may well be the main reason for the Brandenburg teachers' more negative evaluations for inclusive education. Apparently, the issue of the expected extra work must first be resolved. The importance of teacher support is illuminated by the observed association between teacher stress and lack of support in a 
situation in which a child with SEN was placed in a regular classroom (Talmor, Reiter, and Feigin 2005).

This study's limitations include the low return rate of the survey both in Finland and Brandenburg, which might have predisposed the results to a systematic error. However, this possibility is lowered by the observation that teacher attitudes towards inclusion have not been found to be associated with the reported return rate of the survey (Scruggs and Mastropieri 1996). Additionally, the Finnish and German participants did not exactly teach the same grade levels, because the German sample also included the teachers from the Gymnasium level (grades 11-13). Nonetheless, this did not seem to be a major problem because no statistically significant differences were observed among the various teacher categories. The differences of educational organizations between the states may pose challenges to the international comparison of teacher attitudes towards inclusive education. However, in the case of Finland and Brandenburg, enough similarity was guaranteed in the issues of teachers' qualifications, the definition of special needs students and the diagnostic categories applied to make the test items comparable in both states.

It is recommended that future studies pay attention to the 'extra work' issue raised by the majority of the teachers in the present study. The teacher opinions on the needed resources may of course be unrealistic and exaggerated, especially if they have no personal experience in the implementation of inclusive education. Moreover, there is no absolute measure to determine how much resources are actually needed. This is so because the 'special needs' concept is imprecise in itself, and students' needs can hardly be conceptualised in a single dichotomy of general and special types (Bowman 1986). The issue of resources is also a delicate matter because the need for extra support probably reflects the individual level of teacher competence as well. Where one teacher fails without extra support, another may prosper. 
For the promotion of inclusive education, the teachers' concerns about the possible extra work must be addressed. The best answer is perhaps the statutory provision that guarantees extra support for a teacher when a child with SEN is placed in the mainstream classroom. However, three problems emerge from this proposition. First, the required resources cannot be precisely defined because the concept of special needs lacks clarity. Second, the extra resources required also depend on environmental factors, of which the specific competence level of the mainstream teacher is the most important. Third, the proposed legislation may also elicit the teachers' resistance because it diminishes their autonomy. If the student placement and resources are coupled, it may no longer be the teachers' choice whether or not they want the children with SEN in their classrooms. This may be the reason why such guarantees rarely occur in the national school legislation, on which teachers often exercise a strong influence.

\section{References}

Act on Basic Education 1998. Finlex 628/1998 [in Finnish].

http://www.finlex.fi/fi/laki/ajantasa/1998/19980628?search\%5Btype\%5D=pika\&searc $\underline{\mathrm{h} \% 5 \mathrm{Bpika} \% 5 \mathrm{D}=\text { perusopetuslaki }}$

Act on the Funding of Education and Culture. 2009. Finlex 29.12.2009/1705 [in Finnish]. http://www.finlex.fi/fi/laki/ajantasa/2009/20091705

Amt für Statistik Berlin-Brandenburg. 2013. Statistischer Bericht B 1-j/12.

Allgemeinbildende Schulen im Land Brandenburg Schuljahr 2012/2013. [Statistical report. Schools of general education in Brandenburg 2012/2013]

https://www.statistik-berlin-brandenburg.de/Publikationen/Stat_Berichte/2013/SB_B0 1-01-00_2012j01_BB.pdf

Associazione TreeLLe, and Caritas Italiana e Fondazione Agnelli. 2011. Gli Alumni con Disabilità nella Scuola Italiana: Bilancio e Proposte [The Inclusion of Children with 
Disabilities in the Italian School System: Key Figures and Recent Trends]. Trento: Erickson.

Australian Bureau of Statistics. 2013. Most School Children with a Disability Attend Regular Classes. http://www.abs.gov.au/Ausstats/abs@.nsf/dd0ca10eed681f12ca2570ce0082655d/7b942 0eac17220dcca257bbf001629cc!OpenDocument

Bildungskomission der Länder Berlin und Brandenburg. 2003. Bildung und Schule in Berlin und Brandenburg - Herausforderungen und gemeinsame Entwicklungsperspektiven [Education and schools in Berlin and Brandenburg - challenges and common development prospects] https://www.berlin.de/imperia/md/content/sen-bildung/bildungspolitik/bericht_bildun gskommission.pdf?start\&ts=1164109157\&file=bericht_bildungskommission.pdf

Bowman, I. 1986. "Teacher-training and the Integration of Handicapped Pupils: Some Findings from a Fourteen-Nation UNESCO Study." European Journal of Special Needs Education 1(1): 29-38. DOI:10.1080/0885625860010105

Canevaro, A., ed. 2007. L'integrazione Scolastica degli Alunni con Disabilità. Trent'anni di Inclusione nella Scuola Italiana [School Integration of Students with Disabilities. Thirty Years of Inclusion in Italian Schools]. Trento: Erickson.

Cornoldi, C., A. Terreni, T. E. Scruggs, and M. A. Mastropieri. 1999. "Teacher Attitudes in Italy after Twenty Years of Inclusion”. Remedial and Special Education 19 (6): 350356. doi: $10.1177 / 074193259801900605$

Engelbrecht P., H. Savolainen, M. Nel, and O-P Malinen. 2013. "How Cultural Histories Shape South African and Finnish Teachers' Attitudes towards Inclusive Education: A Comparative Analysis.” European Journal of Special Needs Education 28 (3): 305-318. DOI: $10.1080 / 08856257.2013 .777529$ 
Etzioni, A. 1964. Modern Organizations. Englewood Cliffs, NJ: Prentice-Hall.

European Agency for Development in Special Needs Education. 1999. Financing of Special Needs Education: A Seventeen-Country Study of the Relation between Financing of Special Needs Education and Integration. Middelfart: European Agency for Development in Special Needs Education. http://www.european-agency.org/publications/ereports/financing-of-special-needs-educ ation/financing-of-special-needs-education

European Agency for Development in Special Needs Education. 2012. Special Needs Education Country Data. https://www.european-agency.org/publications/ereports/sne-country-data-2012/sne-co $\underline{\text { untry-data-2012 }}$

Finnish National Board of Education. 2015. Basic education. http://www.oph.fi/english/education_system/basic_education

Forlin, C., Earle, C., Loreman, T. and Sharma, U. 2011. The Sentiments, Attitudes, and Concerns about Inclusive Education Revised (SACIE-R) Scale for Measuring Pre-service Teachers' Perceptions about Inclusion. Exceptionality Education International, 21 (3): 50-65.

Horner, R. H., Sugai, G., Todd, A. W., and Lewis-Palmer, T. 2005. Schoolwide Positive Behaviour Support. In L. M. Bambara and L. Kern (Eds.), Individualized Supports for Students with Problem Behaviours (pp. 359-390). New York, NY: Guilford Press.

Kivinen, O., and Kivirauma, J. 1988. Classification, Selection, and Schooling. Special Education in the Finnish School System in the 20th Century. Sociological Studies Series A No. 13. Turku: University of Turku.

Kuntatyönantajat. 2015. Yleisimmät Ammattinimikkeet [The Most Common Occupational Titles]. 
http://www.kuntatyonantajat.fi/fi/ajankohtaista/tilastot/henkilosto/yleisimmat-ammattin imikkeet/Sivut/default.aspx

Landesregierung Brandenburg. 2002. Gesetz über die Schulen im Land Brandenburg. In der Fassung der Bekanntmachung vom 2. August 2002 (GVB1.I/02, [Nr. 08], S.78). [Law on schools in the state of Brandenburg. In the version published August, 2, 2002] http://bravors.brandenburg.de/gesetze/bbgschulg_2015 3

Leyser, Y., Kapperman, G. and Kellerm R. 1994. Teacher Attitudes toward Mainstreaming: a Cross-cultural Study in Six Nations. European Journal of Special Needs Education, 9 (1): 1-15. DOI: 10.1080/0885625940090101

Ministerium für Bildung, Jugend und Sport. 2016. Vorbereitunsgsdienst [Preparatory service]. http://www.mbjs.brandenburg.de/sixcms/detail.php/89617

Ministerium für Bildung, Jugend und Sport. 2015. Bildung im Land Brandenburg [Education in the state of Brandenburg]. http://www.mbjs.brandenburg.de/sixcms/detail.php/lbm1.c.226943.de

Moberg, S. 2003. "Education for All in the North and the South: Teachers' Attitudes towards Inclusive Education in Finland and Zambia.” Education and Training in Developmental Disabilities 38: 417-428.

National Advisory Board on Research Ethics in Finland. 2009. The Ethical Principles of Research in the Humanities and Social and Behavioural Sciences and Proposals for Ethical Review. http://www.tenk.fi/sites/tenk.fi/files/eettisetperiaatteet.pdf

National Center for Education Statistics. 2016. Digest of Education Statistics. https://nces.ed.gov/programs/digest/d13/tables/dt13 204.60.asp

Saloviita, T. 2015. “Measuring Pre-service Teachers' Attitudes towards Inclusive Education: Psychometric Properties of the TAIS Scale.” Teaching and Teacher Education 52: $66-72$. 
Saloviita, T., and Leskinen, M. 2016. Teacher Satisfaction toward the Educational Placement of Students with Special Educational Needs. International Journal of Human Sciences, 13, (1): 1792-1796. http://dx.doi.org/10.14687/ijhs.v13i1.3675

Savolainen, H., P. Engelbrecht, M. Nel, and O-P. Malinen. 2012. Understanding Teachers' Attitudes and Self-Efficacy in Inclusive Education: Implications for Pre-Service and In-Service Teacher Education. European Journal of Special Needs Education, 27 (1): 51-68. DOI: 10.1080/08856257.2011.613603

Scruggs, T. E., and M. A. Mastropieri. 1996. "Teacher Perceptions of Mainstreaming/Inclusion, 1958-1995: A Research Synthesis.” Exceptional Children 63 (1): $59-74$.

Skrtic, T. M. 1991. Behind Special Education. Critical Analysis of Professional Culture and School Organization. Denver, CO: Love Publishing.

SopV. 2007. Verordnung über Unterricht und Erziehung für Schülerinnen und Schüler mit sonderpädagogischem Förderbedarf [Regulation on teaching and education for pupils with special educational needs]. http://bravors.brandenburg.de/de/verordnungen-212414\#8

Statistics Canada.2012. Canadian Survey on Disability. http://www23.statcan.gc.ca/imdb/p2SV.pl?Function=getSurvey\&SDDS=3251

Statistics Finland. 2015a. Liitetaulukko 7. Erityistä Tukea Saaneet Peruskoulun Oppilaat [Appendix Table 7. Primary school students with SEN] http://www.stat.fi/til/erop/2014/erop_2014_2015-06-11_tau_007_fi.html

Statistics Finland. 2015b. Liitetaulukko 5. Erityistä Tukea Saaneet Peruskoulun Oppilaat Opetuksen Toteutuspaikan Mukaan 2012 [Appendix Table 5. Students with SEN according to place of teaching] http://www.stat.fi/til/erop/2012/erop_2012_2013-06-12 tau 005 fi.html 
Statistics Finland. 2015c. Liitetaulukko 8. Osa-aikaista Erityisopetusta Saaneet Peruskoulun Oppilaat [Appendix Table 8. Students in part-time special education]http://www.stat.fi/til/erop/2013/erop_2013_2014-06-12_tau_008_fi.html

Statistics Finland. 2015d. Tehostetun Tuen Piirissä Entistä Useampi Peruskoulun Oppilas [An increasing number of primary school students within the scope of enhanced support] http://www.stat.fi/til/erop/2014/erop_2014_2015-06-11 tie 001_fi.html

Talmor, R., Reiter, S., and Feigin, N. 2005. Factors Relating to Regular Education Teacher Burnout in Inclusive Education. European Journal of Special Needs Education, 20 (2): 215-229. DOI: 10.1080/08856250500055735

UNESCO 1994. The Salamanca Statement and Framework for Action on Special Needs Education. World Conference on Special Needs Education: Access and Quality. Salamanca, Spain 7-10. June 1994

United Nations. 2006. Convention on the Rights of People with Disabilities. http://www.un.org/disabilities/default.asp?navid=15\&pid=150

United Nations. 2015. United Nations Treaty Collection.

https://treaties.un.org/Pages/ViewDetails.aspx?src=TREATY\&mtdsg_no=iv-15\&chapt $\underline{\mathrm{er}=4 \& \text { lang }=\mathrm{en}}$

van der Veen, I., E. Smeets, and M. Derriks. 2010. "Children with Special Educational Needs in the Netherlands: Number, Characteristics and School Career." Educational Research 52 (1): 15-43. DOI: 10.1080/00131881003588147

Webster, R., P. Blatchford, P. Bassett, P. Brown, C. Martin, and A. Russell. 2010. "Double Standards and First Principles: Framing Teaching Assistant Support for Pupils with Special Educational Needs.” European Journal of Special Needs Education 25 (4): 319-336. DOI: 10.1080/08856257.2010.513533 
Table 1

Percentage of teachers who agree or strongly agree with each statement in the TAIS, $t$-values counted from the means, and the values of Cohen's $d$

\begin{tabular}{|c|c|c|c|c|c|}
\hline Item & $\mathrm{F}^{*}$ & $\mathrm{~B}^{*}$ & $t$ & $p$ & $d^{* *}$ \\
\hline $\mathrm{N}$ & 298 & 163 & & & \\
\hline Expected outcomes & $\%$ & $\%$ & & & \\
\hline $\begin{array}{l}\text { 1. Children with special educational needs (SEN) learn best in } \\
\text { their own special education classes where they have specially } \\
\text { trained teachers. }(\mathrm{R})^{* * *}\end{array}$ & 54 & 56 & -3.7 & 0.000 & -0.35 \\
\hline $\begin{array}{l}\text { 6. The best result is achieved if each child with SEN is placed in a } \\
\text { special education classroom that best suits him/her. (R) }\end{array}$ & 43 & 49 & -3.2 & 0.002 & -0.31 \\
\hline $\begin{array}{l}\text { 10. The learning of children with SEN can be effectively supported } \\
\text { in mainstream classrooms as well. }\end{array}$ & 54 & 25 & 4.2 & 0.000 & 0.41 \\
\hline \multicolumn{6}{|l|}{ Rights of the child } \\
\hline $\begin{array}{l}\text { 3. It is the right of a child with SEN to be placed in a special } \\
\text { education classroom. (R) }\end{array}$ & 73 & 85 & -5.7 & 0.000 & -0.56 \\
\hline $\begin{array}{l}\text { 9. A child with SEN should be transferred to a special education } \\
\text { classroom in order not to violate his/her legal rights. (R) }\end{array}$ & 35 & 49 & -3.9 & 0.000 & -0.38 \\
\hline \multicolumn{6}{|l|}{ Workload of the teacher } \\
\hline $\begin{array}{l}\text { 5. The teachers' workload should not be increased by compelling } \\
\text { them to accept children with SEN in their classrooms. (R) }\end{array}$ & 56 & 85 & -10.6 & 0.000 & -1.0 \\
\hline $\begin{array}{l}\text { 8. Integrated children with SEN create extra work for teachers in } \\
\text { mainstream classrooms. (R) }\end{array}$ & 59 & 90 & -11.1 & 0.000 & -1.14 \\
\hline \multicolumn{6}{|l|}{ Inclusion as a value } \\
\hline $\begin{array}{l}\text { 2. The children with emotional and behavioural problems should } \\
\text { be educated in mainstream classrooms, with the provision of } \\
\text { adequate support. }\end{array}$ & 22 & 46 & -7.8 & 0.000 & -0.75 \\
\hline $\begin{array}{l}\text { 4. Children with attention deficit hyperactivity disorder (ADHD) } \\
\text { should be admitted in mainstream classrooms with adequate } \\
\text { support. }\end{array}$ & 44 & 56 & -4.4 & 0.000 & -0.43 \\
\hline $\begin{array}{l}\text { 7. The students with SEN should be educated in mainstream } \\
\text { classrooms, as much as possible. }\end{array}$ & 49 & 23 & 3.5 & 0.000 & 0.35 \\
\hline
\end{tabular}

Note $1: * \mathrm{~F}=$ Finland, $\mathrm{B}=$ Brandenburg

Note 2: $* *$ Negative value $=$ Brandenburg has a greater mean than Finland.

Note 3: *** The scoring of items marked with $\mathrm{R}$ is reversed when counting the sum total. 
Table 2

Finnish and Brandenburg teachers' attitudes towards inclusive education, as measured by TAIS (midpoint of the scale is 22.5)

\begin{tabular}{ccccccc}
\hline Teacher category & $\mathrm{n}$ & Mean & SD & $d f$ & Test & $p$ \\
\hline Brandenburg & 163 & 24.14 & 6.29 & 2,160 & $F=2.924$ & 0.057 \\
Grundschule & 35 & 23.94 & 5.56 & & & \\
Hauptschule & 37 & 26.27 & 6.20 & & & \\
Gymnasium & 91 & 23.35 & 6.45 & & & \\
Finland & 298 & 28.44 & 7.97 & 296 & $t=0.601$ & 0.548 \\
Classroom teacher & 188 & 27.60 & 7.82 & & & \\
Subject teacher & 110 & 27.04 & 7.63 & & & \\
Finland vs. Brandenburg & 461 & & & 459 & $t=4.59$ & 0.000 \\
\hline
\end{tabular}

